\title{
The Problems for the Treatment of Traumatic Brain Injury : From the Joint Symposium of Annual Meeting of JNST 2014 and JAST 2014
}

\author{
Hiroyuki Yokota, M.D. \\ Department of Emergency and Critical Care Medicine, Post Graduate School of Medicine, Nippon Medical School
}

Because of the high mortality and the high morbidity rate, the management and the treatment of severe traumatic brain injury is very important and difficult in the field of traumatology. The treatment of patients with multiple injuries complicated with brain injury requires close collaboration between trauma surgeons specializing in the treatment of torso trauma and neurosurgeons. The Japanese trauma care system has progressed remarkably with the advancement of standard procedures to decrease preventable trauma deaths and with the publication of guidelines for the treatment and management for severe traumatic brain injury. And with Japan's aging society, the increase in the number of traumatic brain injuries in older adults is a serious problem. Elderly patients with traumatic brain injuries generally have worse outcomes compared with younger patients due to their weakened physical status and of the presence of other age-related disease. To properly evaluate severe traumatic brain injury, especially in elderly patients, many kinds of intracranial monitoring and biomarker measurements s have been employed.

Under a common comprehension of the difficulty faced in the treatment and management of traumatic brain injury, the joint symposium between the annual meeting of Japanese Association of Surgeons of Trauma (JAST) and Japan Society of Neurotraumatology (JNST) was held in 2014. In this symposium, many problems as well as the approaches and trials used for treating traumatic brain injury, including treatments for elderly patients, were discussed in order to improve patient' outcomes.

(Received July 16, 2014; accepted September 1, 2014)

Key words : traumatic brain injury, trauma data bank, aging society, neurochemical monitoring

Jpn J Neurosurg（Tokyo）23:942-950, 2014

\section{はじめに}

頭部外傷は外傷の中でも頻度や死亡率が高く，外傷学 においては重要な位置付けがなされている。頭部外傷は 主として脳神経外科医によって重症度評価や治療がなさ れることが多く, 多発外傷の場合は体幹外傷を専門とす
る外傷医との密接な連携が必要である，近年，外傷診療 の質の向上や「防ぎ得る外傷死」の回避のために外傷医 と脳神経外科医の協力によってさまざまな体制が構築さ れつつある。 また, 高齢化社会を反映して高歯者外傷が 急増し, 頭部外傷も同様である. 高齢者外傷では年齢に よる身体的, 生理的脆弱性だけではなく, 多臟器疾患を 
既往に抱えていることが多いため, 若年者とは異なった 対応が必要となる。このような視点から外傷学における 頭部外傷の位置付けについて考察を試みる。

\section{外傷における頭部外傷の疫学}

2013 年の人口動態統計月報年計（概数）の概況 ${ }^{7)} に よ$ ると「不慮の死」は年間 39,435 人で死因の 6 位である. ま た，年龄別の死因では 5 9 歳で 1 位，1４歳，10２9 歳で 2 位となっている。「不慮の死」の中で外傷を起因 とする交通事故, 転倒・転落は合計 13,251 人で, 2012 年の 14,175 人と比較すると減少している.しかし, 2010 年の外傷死 17,775 人の中で, 頭部外傷による死亡は 11,087 人で $62.7 \%$ を占め, 外傷死における頭部外傷は大 きな位置を占めている.

一方，わが国の代表的な外傷診療施設が登録している 日本外傷データバンクの統計 $(2007 \sim 2012$ 年) では, 全 外傷登録 95,924 名中, 頭部外傷は 29,876 人であり, 部 位別では下肢外傷 36,534 人に次いで多かった ${ }^{12)}$.また, 上記のように頭部外傷は外傷の中でも頻度が高く, 死亡 する場合も多い.さらに, 救命されてもさまざまな後遺 症が残存することがあり, その支援のために多くの社会 資源を必要とすることが大きな課題で, 外傷学における 頭部外傷の重要性を示唆している。

\section{外傷初期診療体制構築の経緯と頭部外傷}

\section{1 防ぎ得る外傷死 (preventable trauma death : PTD）とその回避}

1970 年代後半の救急医療体制の確立，いわゆる初期, 二次, 三次救急医療機関の整備により, 外傷診療の整備 が整っていると考元られていたわが国の医療であるが, 平成 13 年度厚生労働科学特別研究事業「救命救急セン 夕ーにおける重症外傷患者への対応の充実に向けた研 究」の結果は, その後の外傷診療体制の構築に大きな影 響を与えた。報告書は当時の全国救命救急センターにお ける外傷死亡症例のうち, 適切な診療が行われていれば 回避できた可能性の高い死亡 (防ぎ得る外傷死, preventable trauma death：PTD）が，38.6\%であったことを報告 した。救命救急センターは地域の救急医療に中心的な役 割をもつ医療機関であり, 報告された内容は救急医療に 関わる医療機関や行政に大きな影響を与えた. PTDによ る社会的損失は多大であり, 特に外傷死亡が 20〜30 歳 台までの若年生産人口における死因の第 1 位であるこ とから考えると, その回避はきわめて重要で, 早急な対
応の必要性が強調された ${ }^{6)}$.

同報告書は, PTD が初期の生理学的異常に対する不 適切な対応や治療によって発生したとし, 外傷初期診療 体制の充実化を強調した。また, PTD の中には頭部外傷 症例が多く含まれていることも指摘され, 意識障害や脳 ヘルニア徵候を示した重症頭部外傷における呼吸・循環 の安定化の重要性が示された。

\section{2 病院前救護と外傷初期診療の標準化}

そのような状況下のもとに日本救急医学会や日本外傷 学会はPTD 回避を目的として外傷初期診療の標準化 コース開発に着手し，その後全国的に急速に普及したの が外傷初期診療コース (Japan Advanced Trauma Evaluation and Care: JATEC) である. JATEC は ATLS (Advanced Trauma Life Support) など欧米の外傷初期診 療コースを基盤として開発されたコースで 2003 年から 全国的にコース開催が行われ, その内容は講義と実技か らなる. 8 つのスルステーションと 4 つのケースシナ リオからなる実技実習においてシミュレーター等を使用 して実践に即したコースが年間 32 回（2014 年度からは 40 回を予定）開催されている.

また, 日本臨床救急医学会と日本救急看護学会は 2004 年から外傷初期対応を指向した看護コースの開発 に着手し，2007 年 11 月から正式なコース（外傷初期看 護ガイドライン: JNTEC) が開催されている. JNTEC は JATEC と同様にPTD の回避をその目標とし, JATEC と の整合性を考慮しつつ, 看護師の視点から外傷患者の確 実なアセスメント, 適切な診療介助や外傷看護が実践で きる看護師の育成を目的としたものである。

PTD 回避のためには, 上記のような呼吸や循環の安定 化を目的とした救急初療室での医療スタッフの知識や技 術の標準化だけではなく, 救急現場から適切な医療機関 に搬送する救急隊員の知識や技術向上も重要である. 米 国では外傷システムの整備と外傷初療の標準化により 1960 年前半〜 1980 年後半にかけて, PTD を劇的に減少 させた実績がある ${ }^{6)}$. 本邦においては 2003 年 6 月に Japan Prehospital Trauma Evaluation and Care (JPTEC) 協 議会が発足し, 現場や搬送途上における観察と処置の標 準化を目指した病院前外傷教育プログラムが開発され $た^{8)}$.

このように外傷，特に大きなエネルギーが作用したと 思われる外傷では救急現場から病院初療室まで呼吸や循 環の評価と安定化を優先した外傷診療体制の構築が急速 に整備された。そのような中で, 日本神経外傷学会 (現： 日本脳神経外傷学会）は「重症頭部外傷の治療と管理の 
Table 1 Skull injury classification

\begin{tabular}{|c|c|c|c|c|}
\hline & & Mild & Moderate & Severe \\
\hline \multirow{2}{*}{ 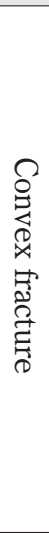 } & $\begin{array}{l}\text { Linear } \\
\text { fracture }\end{array}$ & $\begin{array}{l}\text { Both with (1) and with (2) } \\
\text { (1)Fracture line does not cross } \\
\text { to vascular mark } \\
\text { (2) Fracture line is not over } \\
\text { venous sinus }\end{array}$ & $\begin{array}{l}\text { Either with (1) or with (2) } \\
\text { (1)Fracture line crosses to } \\
\text { vascular mark } \\
\text { (2) Fracture line is over venous } \\
\text { sinus }\end{array}$ & \\
\hline & $\begin{array}{l}\text { Depressed } \\
\text { fracture }\end{array}$ & $\begin{array}{l}\text { Both with (1) and with (2) } \\
\text { (1)Depressed less than } 1 \mathrm{~cm} \\
\text { (2) Closed wound }\end{array}$ & $\begin{array}{l}\text { Both with (1) and with (2) } \\
\text { (1)Depressed less than } 1 \mathrm{~cm} \\
\text { (2) Open wound without liquor- } \\
\text { rhea }\end{array}$ & $\begin{array}{l}\text { Either with (1) or with (2), or } \\
\text { with (3) } \\
\text { (1)Depressed over } 1 \mathrm{~cm} \\
\text { (2) Open wound and with liquor- } \\
\text { rhea } \\
\text { (3)Venous circulatory distur- } \\
\text { bance due to compression of } \\
\text { sinus }\end{array}$ \\
\hline & $\begin{array}{l}\text { Basal skull } \\
\text { fracure }\end{array}$ & & With and/or without liquorrhea & $\begin{array}{l}\text { Otorrhea and/or rhinorrhea } \\
\text { with massive bleeding }\end{array}$ \\
\hline
\end{tabular}

ガイドライン 第 2 版」15)では JPTEC や JATEC の考え 方を大きく取り入れ, 重症頭部外傷の急性期治療におけ る呼吸と循環の評価と安定化が強調され, 現行の第 3 版 にも引き続きその考え方が継続されている ${ }^{16)}$.

\section{3 外傷医と脳神経外科医による頭部外傷分類}

外傷医が治療の対象となるような頭部外傷の初期診療 に関わる際には脳神経外科医との連携が重要となる. PTD 回避のために全国で盛んに開催されている JATEC においても，重篤な頭部外傷，たとえば「切迫する D」 では速やかに脳神経外科医にコンサルトすることが強調 されている。しかしながら，外傷医と脳神経外科医の共 通言語としての適切な頭部外傷分類が存在しないため に，その必要性が従来から強調されてきた。このような 背景から日本外傷学会と日本神経外傷学会（現：日本脳 神経外傷学会）は急性期頭部外傷患者を治療する際に外 傷医と脳神経外科医がともに使用できる頭部外傷分類を 作成し，公表した ${ }^{14) 25) 26)}$ 。 なお，本分類を使用するにあ たっては以下の点を確認して使用することになってい る。すなわち,

・頭部外傷の救急患者が来院した場合にその初療を担当 する外傷医や救急医などの医師が脳神経外科医と共同で 治療する際の共通言語として使用する分類である。

- 分類は原則として Gennarelli らの分類を基礎として, 臨床症候と急性期 CT 等の画像所見を中心に作成したも のである。したがって，本分類を使用するにあたっては 必要最小限の神経学的所見の把握と画像は必須である.

- 軽症は観察入院, 中等症は入院して厳重な管理のもと に経過観察，もしくは予防的に外科的処置や頭蓋内圧モ
ニターの適用を考慮する状態とする。重症は外科的処置 や頭蓋内压モニターの設置等集中治療を行うことを前提 とする状態である。

・神経学的所見は経時的に変化するため, 継続的な評価 が重要である。すなわち，軽症，中等症，および重症の 評価は変更される可能性があり，来院時の分類が絶対的 なものではない.

・重症と判断された場合にはその対応や治療等に関して 速やかに脳神経外科医に相談することを原則とする.

- 本分類でいう局所性脳損傷は頭蓋の特定の部位に作用 した衝撃が神経学的症候の根拠となっている場合で，画 像上は脳挫傷，急性硬膜外血腫，急性硬膜下血腫，ある いは脳内血腫である。一方，びまん性脳損傷（広義）は 主として回転外力や加速度による一次性脳損傷と二次性 脳損傷が神経学的症候の根拠となっている場合とした。 画像上, 前者はびまん性脳損傷 (狭義), くも膜下出血 で, 後者はショックや低酸素血症で生じるびまん性脳腫 脹である。

また，分類の実際は頭蓋骨骨折，局所性脳損傷，びま ん性脳損傷の 3 つからなる。

\section{1. 頭蓋骨骨折 (Table 1)}

急性硬膜外血腫の発生等の可能性から頭蓋骨の血管溝 や静脈洞を横切る骨折では，原則として厳重な管理のも とに経過観察する中等症と分類されている。また，大量 の耳出血，鼻出血を伴う場合は，血管損傷を伴った頭蓋 底骨折の可能性があるので重症と分類されている。

\section{2. 局所性脳損傷 (Table 2)}

局所性脳損傷で記載されている脳へルニア徵候とは, テント切痕ヘルニアの有無を意味している。神経学的所 
Table 2 Focal brain injury classification

The patients with the sign of uncal herniation is having anisocoria, or hemiparesis, or Cushing's phenomenon.

Mass effect on CT is the sign with the midline shift over $5 \mathrm{~mm}$ on the slice of Monro's Foramen on CT.

\begin{tabular}{c|l|l|l}
\hline & \multicolumn{1}{|c|}{ Mild } & \multicolumn{1}{|c}{ Moderate } & \multicolumn{1}{|c}{ Severe } \\
\hline CC & Both with (1) and with (2) and with & Both with (1) and with (2) and with & Either with (1) or with (2), or with \\
AEDH & (3) & (3) & (3) \\
ASDH & (1)GCS 14, 15 & (1)GCS 9 13 & (1) GCS 3 8 \\
ICH & (2) Without sign of uncal herniation & (2)Without sign of uncal herniation & (2) With sign of uncal herniation \\
& (3)Without mass effect on CT & (3)Without mass effect on CT & (3)With mass effect on CT \\
\hline
\end{tabular}

$\mathrm{CC}$ : cerebral contusion, AEDH : acute epidural hematoma, ASDH: acute subdural hematoma, ICH: intracerebral hemorrhage

Table 3 Diffuse brain injury classification

The sign of uncal herniation is having anisocoria, or hemiparesis, or Cushing's phenomenon.

\begin{tabular}{|c|c|c|c|}
\hline & Mild & Moderate & Severe \\
\hline $\begin{array}{c}\text { Diffuse brain } \\
\text { injury }\end{array}$ & $\begin{array}{l}\text { Transient neurological deficit } \\
\text { without loss of consciousness } \\
\text { (mild concussion) }\end{array}$ & $\begin{array}{l}\text { Loss of consciousness with the } \\
\text { recovery within } 6 \text { hours. Some } \\
\text { cases have transient neurological } \\
\text { deficit. } \\
\text { (classical concussion) }\end{array}$ & $\begin{array}{l}\text { Loss of consciousness with } \\
\text { prolonged coma } \\
\text { (case with the sign of brainstem } \\
\text { dysfunction is critical) }\end{array}$ \\
\hline Subarachnoid & & Located partially at basal cistern & Located diffusely at basal cistern \\
\hline $\begin{array}{l}\text { Diffuse brain } \\
\text { swelling }\end{array}$ & $\begin{array}{l}\text { Primary brain injury and both } \\
\text { with (1) and with (2) } \\
\text { (1) GCS } 14,15 \\
\text { (2) Slight brain swelling }\end{array}$ & $\begin{array}{l}\text { Primary brain injury and both with } \\
\text { (1) and with (2), and with (3) } \\
\text { (1) GCS } 9-13 \\
\text { (2)Without the sign of uncal } \\
\text { herniation } \\
\text { (3) Brain selling with the presence } \\
\text { of basal cistern on CT }\end{array}$ & $\begin{array}{l}\text { - Primary brain injury and either } \\
\text { with (1) or with (2), or with (3) } \\
\text { (1) GCS 3-8 } \\
\text { (2)With the sign of uncal herniation } \\
\text { (3) Compression and/or absence of } \\
\text { basal cistern } \\
\text { - Secondary brain damage }\end{array}$ \\
\hline
\end{tabular}

見では意識障害を伴う瞳孔不同，片麻痺，Cushing 徵候 のいずれかが出現した場合や画像上，正中線構造の偏位 が $5 \mathrm{~mm}$ 以上 (モンロー孔レベルのスライス)，もしくは 脳底槽が圧排，消失している所見を脳へルニア徴候と定 義している.

\section{3. びまん性脳損傷（Table 3)}

回転外力や加速度に上る一次的脳損傷や二次的脳損傷 が神経学的症候の原因となっている場合で, 外傷性くも 膜下出血や脳腫脹を伴うことがある.

\section{高齢者社会と頭部外傷}

\section{1 高齢化の現状と将来}

一般的に高齢化率 (65 歳以上の人口が総人口に占める 割合）によって, (1)高齢化社会（高齢化率 7〜 $14 \%$ ), (2) 高齢社会（高齢化率 14 21\%), (3)超高齢社会（高齢化 率 $21 \%$ 以）と呼んでいるが，日本の国勢調査の結果で は 1970 年で高齢化率 $7.1 \% ， 1995$ 年で $14.5 \%$ となり
2007 年に $21.5 \%$ となって超高齢社会となったといわれ ている.

内閣府は将来推計人口から 50 年後の全国の出生, 死 亡，および国際人口移動について予想をした。これらに 基づいてわが国の将来の人口規模ならびに年齢構成等の 人口構造の推移について, 国立社会保障・人口問題研究 所は「日本の将来推計人口」で出生数・死亡数の推計結 果を公表した ${ }^{12)}$ 。報告によると日本の総人口は，長期の 人口減少過程に入り, 2026 年には人口 1 億 2,000 万人を 下回り，2048 年には 9,913 万人となり，2060 年には 8,674 万人になると推計している.

総人口が減少する中でも高齢者が増加することにより 高齢化率は上昇を続け，2013 年には高齢化率が $25.1 \%$ で 4 人に 1 人となり, 2035 年に $33.4 \%$ で 3 人に 1 人と なる. 2042 年以降は高齢者人口が減少に転じても，高齢 化率は上昇を続け，2060 年には $39.9 \%$ に達して国民の 約 2.5 人に 1 人が 65 歳以上の高齢者となる社会が到来 すると推計している．総人口に占める 75 歳以上人口の 


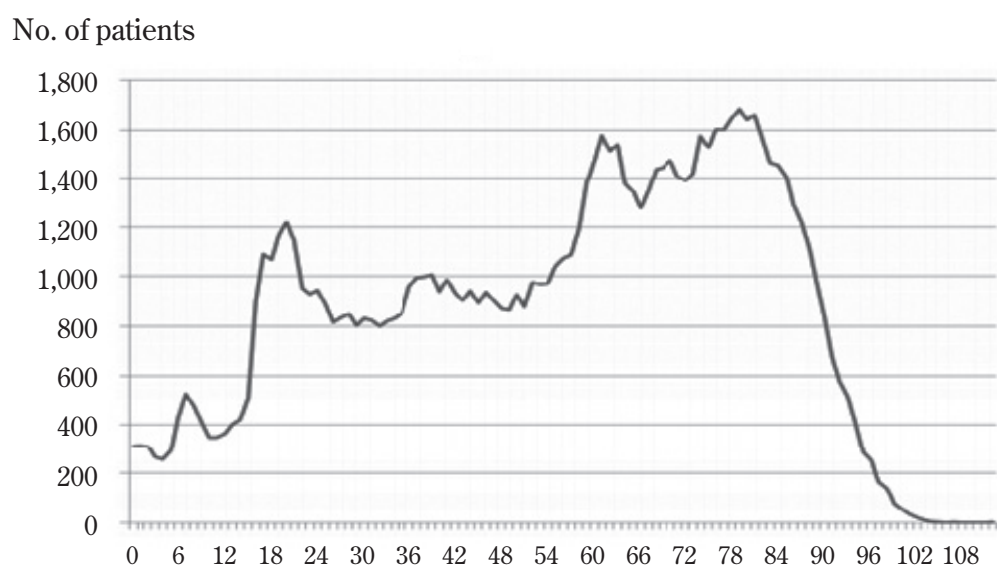

Age

Fig. 1 Number of cases and age distribution $(n=95,924)$

(http://www.jtcrjatec.org/traumabank/dataroom/data/ JTCR2013.pdf)

割合も上昇を続け,いわゆる「団塊ジュニア」(1971〜1974 年に生まれた人) が 75 歳以上となった後に，2060 年高 齢者人口の対前年度増加数の推移は $26.9 \%$ となり, 4 人 に 1 人が 75 歳以上の高齢者となると推計している.

一方, 高齢人口の増大により死亡数は増加, 死亡率 （人口 1,000 人あたりの死者数）は上昇を続け，2060 年 には，17.7 になると推計されている.

\section{2 高齢化社会と高齢者頭部外傷}

日本外傷データバンクに登録されている 95,924 例の 年齢分布は Fig. 1 のように 18〜20 歳台と高齢者に二峰 性になっているが，高龄者でより高いピークを示してい $ろ^{13)}$.

また，本邦で重症頭部外傷を治療する代表的な施設が 加盟する日本脳神経外傷学会のデータバンクである JNTDB（Japan Neurotrauma Data Bank）には来院時の Glasgow Coma Scale（GCS）が 8 以下，あるいは頭部外 傷に関する外科的手術を行った症例が登録されている が, 過去 3 回デー夕収集が行われ計 3,194 症例の登録が なされた。すなわち, Project 1998 (以下, P1998：1998〜 2001 年, 10 施設, 6 歳以上から登録) 1,002 例, Project 2004 （以下，P2004：2004 2006 年; 19 施設） 1,101 例, および Project 2009 (以下, P2009：2009〜2011 年；22 施 設）1,091 例の登録である.P1998 では明らかに 20２9 歳と 60〜69 歳が 2 つのピークとなる二峰性の分布を示 していたが, P2004 では 20〜29 歳のピークが減少する 反面, 60〜69 歳のピークが増大し, 一峰性の傾向となっ た. 65 歳以上の高齢化率を算出すると, P1998 では
30.5\%であったが, P2004 では 34.6\%, P2009 では 43.9\% と有意な上昇を示し，本邦における重症頭部外傷の高齢 化への著明な傾向が裏付けられた。さらに，高齢者の中 での 75 歳以上の超高齢者の割合も $49.7 \%$ から $52.1 \%$, 58.5\% と有意に増加していた。加えて，P2009 では 70〜 79 歳が年齢分布のピークとなり, 超高齢者の割合が増加 している本邦の頭部外傷の特徵が明らかとなり，急速な 高齢化社会を反映した結果となっている $(\text { Fig. 2 })^{22)}$.

高齢者頭部外傷における生理学的, 解剖学的重症度の 変化を P1998, P2004, P2009 で比較すると, 性別比に有 意な差はなかったが，来院時 GCS は P1998 に平均 6.4 であったが, P2009 では平均 7.2 となり有意に上昇, す なわち来院時の意識障害は軽減化していた。一方, 解剖 学的重症度を示す ISS は 3 群間で有意な差はみられな かったが，CT で円蓋部骨折の有意な減少，頭蓋底骨折 の有意な増加と気脳症，外傷性くも膜下出血の有意な増 加を認めていた。びまん性損傷, 局所性損傷の比率の比 較では，経年的に局所性損傷の増加，びまん性損傷の減 少を認めた。これらの結果は高齢者頭部外傷の増加，す なわち交通事故などの高エネルギー事故による受傷機転 が減少し, 家庭内や歩行中の転倒など日常生活の中での 重症頭部外傷増加を反映しているものと推察された (Table 4, 5).

また, 高齢者頭部外傷の転帰に関しては, 死亡率が P1998 の 62.7\%から P2009 では 51.1\%へ有意な低下を 認めたが，一方で severe disability（SD）群の有意な増加 を認めた。生存率は P1998 の 37.3\%から P2009 の $48.9 \%$ まで有意な上昇を認めたが, 日常生活に介助・介 


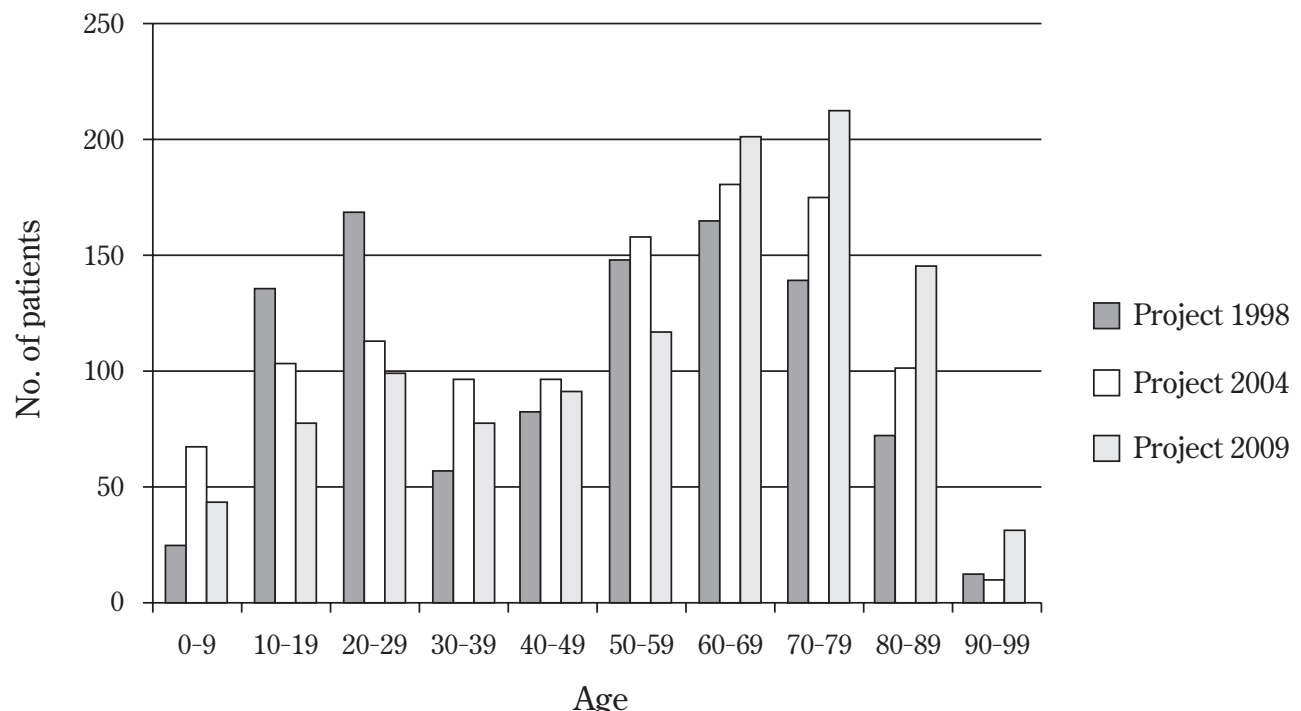

Fig. 2 JNTDB age distribution (from reference 22) JNTDB : Japan Neurotrauma Data Bank

Table 4 Comparison in elderly traumatic injury between P1998, P2004, and P2009 (revised from reference 22)

\begin{tabular}{c|c|c|c|r}
\hline & $\begin{array}{c}\text { P1998 } \\
(\mathrm{n}=1,002)\end{array}$ & $\begin{array}{c}\text { P2004 } \\
(\mathrm{n}=1,101)\end{array}$ & $\begin{array}{c}2009 \\
(\mathrm{n}=1,091)\end{array}$ & $\mathrm{p}^{- \text {value }}$ \\
\hline$\geqq$ 65 years old (\%) & $306(30.6)$ & $380(34.6)$ & $479(43.9)$ & $<0.0001$ \\
Age (mean SD) & $75.3 \pm 7.4^{\dagger}$ & $76.0 \pm 6.9^{*}$ & $77.1 \pm 7.5^{*}$ & 0.0026 \\
GCS on admission & $6.4 \pm 3.5^{+*}$ & $7.0 \pm 3.7^{*}$ & $7.2 \pm 3.8^{\dagger}$ & 0.0125 \\
ISS & $27.0 \pm 11.4$ & $24.9 \pm 11.9$ & $26.3 \pm 14.6$ & 0.0866 \\
Convex fracture (\% in elderly) & $148(48.4 \%)$ & $178(46.8 \%)$ & $185(38.6 \%)$ & $<0.0001$ \\
Basal skull fracture (\% in elderly) & $25(8.2 \%)$ & $48(12.6 \%)$ & $94(19.6 \%)$ & $<0.0001$ \\
Intracranial air (\% in elderly) & $10(3.3 \%)$ & $40(10.5 \%)$ & $66(13.8 \%)$ & $<0.0001$ \\
Traumatic SAH (\% in elderly) & $166(54.2 \%)$ & $220(57.9 \%)$ & $330(68.9 \%)$ & $<0.0001$ \\
Focal injury (\% in elderly) & $135(44.1 \%)$ & $297(78.2 \%)$ & $357(74.5 \%)$ & $<0.0001$ \\
Diffuse injury (\% in elderly) & $171(55.9 \%)$ & $83(21.8 \%)$ & $122(25.5 \%)$ & $<0.0001$ \\
\hline
\end{tabular}

P1998: Project 1998, P2004: Project 2004, P2009： Project 2009

${ }^{\dagger},{ }^{*}: \mathrm{p}<0.05$, Post hoc with Scheffe test

護が必要と思われる SD と vegetative state（VS）の生存 群における割合はP1998 で 63.2\%，P2004 で 67.2\%， P2009 で 68.4\% と徐々に増加傾向を示した.

頭部外傷の一般的特徵として, 転帰は加齢とともに悪 化するといわれており，受傷時年齢は重要な転帰規定因 子の一つとして挙げられている21)。これには高齢者脳組 織の生理的脆弱性自体に原因があると結論している報告 も散見され ${ }^{11) 24)}$, 積極的治療を行っても, 脳組織自体の “老化”により多くの症例が転帰の改善を得られない厳し い現状がある。また，現在のところ高齢者特有の病態を 加味した高齢者に特化した治療やエビデンスレベルの強 いガイドラインはなく，どのような患者にどこまで積極 的治療の判断を行うべきかの判断は難しい. 救急医療に
携わる医療スタッフは治療すべきかの判断に困惑する場 合も経験する，以前，われわれが報告した P2004 のデー 夕からの検討では ${ }^{22)}$ ，若年者に比して高齢者頭部外傷で は有意に積極的治療が少なかったことからも, 高齢者頭 部外傷における治療方針決定の困難さが課題である.

\section{頭蓋内モニタリングの治療への応用}

重症頭部外傷の治療には急性期における呼吸，循環の 安定化を前提に病態に則した適切な治療が求められる。 特に, 他部位損傷を合併する多発外傷の際には呼吸や循 環が不安定であるため，単独頭部外傷と比較して CT な どの画像診断が制約される場合がある。したがって, 頭 
Table 5 Outcome of elderly traumatic injury (revised from reference 22)

\begin{tabular}{c|c|c|c|c}
\hline Project & 1998 & 2004 & 2009 & p-value \\
\hline $\begin{array}{c}\text { No. of cases } \\
\text { Duration of }\end{array}$ & 306 & 380 & 479 & \\
$\begin{array}{c}\text { admission (day) } \\
\text { Glasgow Outcome } \\
\text { Scale (No, \%) }\end{array}$ & $27.4 \pm 42.4$ & $34.2 \pm 51.5$ & $28.7 \pm 42.8$ & 0.1111 \\
GR & $22(7.2 \%)$ & $23(6.1 \%)$ & $27(5.6 \%)$ & 0.6729 \\
MD & $20(6.5 \%)$ & $42(11.1 \%)$ & $47(9.8 \%)$ & 0.1178 \\
SD & $46(15.0 \%)$ & $85(22.4 \%)$ & $99(20.7 \%)$ & 0.0384 \\
VS & $26(8.5 \%)$ & $48(12.6 \%)$ & $61(12.7 \%)$ & 0.1442 \\
D & $192(62.7 \%)$ & $182(47.9 \%)$ & $245(51.1 \%)$ & 0.0003 \\
No. of survivors & $114(37.3 \%)$ & $198(50.8 \%)$ & $234(48.9 \%)$ & 0.0003 \\
$\begin{array}{c}\text { (survivors rate) } \\
\text { No. of dependence } \\
\text { (rate in survivors) }\end{array}$ & $72(63.2 \%)$ & $133(67.2 \%)$ & $160(68.4 \%)$ & 0.6199 \\
\hline
\end{tabular}

蓋内環境を正確に把握する頭蓋内モニタリングの重要性 が強調されている，最近発表された大規模な検討におい ても ICP モニターを使用することで頭部外傷の死亡率 を有意に低下させたことが示されている141717)。しかし， Chesnut $ら^{3)}$ は頭部外傷における頭蓋内圧（intracranial pressure：ICP）モニタリングに関する世界初の randomized control trial(RCT)を南米でのデー夕をもとに発表し た. 彼らは primary endpoint として生存期間と 3,6 力月 後の機能転帰に ICP 測定群と非測定群に有意な差がみ られなかったことを発表しているが，彼ら自身も述べて いるように対象施設や患者背景の相違などが指摘されて いる.

さらに，脳実質損傷や同部位から細胞外に漏出される さまざまなバイオマーカーの動態を把握することで予後 予想や病態推測をする手法が行われている。その中で近 年注目されているのが microdialysis 法による各種バイ オマーカーの動態である ${ }^{910)}$. たとえば, バイオマーカー としてのブドウ糖は脳血流量, 乳酸は虚血状態, グリセ ロールは細胞膜破壊状態, グルタミン酸は細胞障害の程 度を反映するとされ, 症例ごとの病態に合わせた治療選 択の指標になることが期待されている(2)5)23)。われわれの 検討においても重症頭部外傷への脳低体温療法を導入し た際に，若年者に比して高齢者では有意にブドウ糖が低 值で，グリセロールが高值であったことが示され，若年 者と高齢者の脳損傷様式の相違が示唆されている ${ }^{23)}$.

また，容易に測定可能で，治療方針の決定に大きく関 わる凝固線溶系バイオマーカーの存在が注目されてい る. 特に, 受傷 3 時間以内の異常線溶六進が重症頭部外 傷の転帰を不良にする要因であることが注目されてい $3^{19)}$.

\section{外傷関連学会との連携}

体幹外傷や多発外傷の病態や治療を専門とする学術団 体である日本外傷学会と, 頭部外傷の病態研究や治療を 専門とする日本脳神経外傷学会は，前述のようにガイド ライン作成（日本外傷学会, 日本救急医学会監修: 外傷 初期診療ガイドライン改訂第 4 版. 東京, へるす出版, 2012）や外傷分類作成などでさまざまな連携を行ってき た。そのような中，2014 年 3 月に開催された第 37 回日 本脳神経外傷学会 (会長: 高里良男) と同年 6 月に開催 された第 28 回日本外傷学会総会・学術集会 (会長: 横田 裕行）では両学会のジョイントセッションが企画され， それぞれの学会で活躍する頭部外傷治療の専門家による 活発な議論がなされた。議論の内容はドクターカー, ド クターヘリなどの病院前治療から, 救急初療室での対応, 神経集中治療の実際など重症頭部外傷治療の実際に則し たものであった。

\section{まとめ}

外傷の中でも頭部外傷は頻度や死亡率が高く, また救 命された場合の後遺症も大きな問題となるため, 外傷学 においては重要な位置付けがなされている。 また，高齢 化社会を反映して高齢者外傷が急増する背景から, 若年 者とは異なった対応が必要である。そのような中, 体幹 外傷の治療を専門とする外傷医と脳神経外科医が協力し て外傷診療の質の向上や「防ぎ得る外傷死」の回避のた めの体制構築がますます求められている。

本論文の主旨は第 34 回日本脳神経外科コングレス総会 
（2014 年 5 月 17 日）のランチョンセミナー(学会主催) で発 表した。

\section{文 献}

1) Alali AS, Fowler RA, Mainprize TG, Scales DC, Kiss A, de Mestral C, Ray JG, Nathens AB: Intracranial pressure monitoring in severe traumatic brain injury: results from the American College of Surgeons Trauma Quality Improvement Program. J Neurotrauma 30:1737-1746, 2013.

2) Charalambides C, Sgouros S, Sakes D: Intracerebral microdialysis in children. Childs Nerv Syst 26:215-220, 2010.

3) Chesnut RM, Temkin N, Carney N, Dikmen S, Rondina C, Videtta W, Petroni G, Lujan S, Pridgeon J, Barber J, Machamer J, Chaddock K, Celix JM, Cherner M, Hendrix T ; Global Neurotrauma Research Group: A trial of intracranial-pressure monitoring in traumatic brain injury. $N$ Engl J Med 367:2471-2481, 2012.

4) Farahvar A, Gerber LM, Chiu YL, Carney N, Härtl R, Ghajar $\mathrm{J}$ : Increased mortality in patients with severe traumatic brain injury treated without intracranial pressure monitoring. J Neurosurg 117: 729-734, 2012.

5) Feuerstein D, Manning A, Hahemi P, Bhatia R, Fabricius M, Tolias C, Pahl C, Ervine M, Strong AJ, Boutelle MG : Dynamic metabolic response to multiple spreading depolarization in patients with acute brain injury: an online microdialysis study. J Cereb Blood Flow Metab 30: 1343$1355,2010$.

6) 平成 13 年度厚生科学特別研究事業「救命救急センター における重症外傷患者への対応の充実に向けた研究：研 究報告書」

7）厚生労働省：平成 25 年人口動態統計月報年計（概数）の 概況. (http://www.mhlw.go.jp/toukei/saikin/hw/jinkou/geppo/ nengai13/dl/gaikyou25.pdf\#search='平成 25 年の人口動 態統計月報年計 (概数) の概況)

8）JPTEC 協議会テキスト編集委員会編：外傷病院前救護 ガイドライン JPTEC. へるす出版, 2005, p.60.

9) Lakshmanan R, Loo JA, Drake T, Leblanc J, Ytterberg AJ, McArthur DL, Etchepare M, Vespa PM: Metabolic crisis after traumatic brain injury is associated with a novel microdialysis proteome. Neurocrit Care 12:324-336, 2010.

10) Marklund N, Blennow K, Zetterberg H, Ronne-Engström E, Enblad P, Hillered L: Monitoring of brain interstitial total tau and beta amyloid proteins by microdialysis in patients with traumatic brain injuruy. J Neurosurg 110 : 1227-1237, 2009.

11) Maurice-Williams RS: Head injuries in the elderly. $\mathrm{Br} J$ Neurosurg 13:5-8, 1999 .

12）内閣府：平成 23 年度 高齢化の状況及び高齢社会対策の
実施状況．平成 24 年版高齢社会白書．2012。（http:// www8.cao.go.jp/kourei/whitepaper/w-2012/zenbun/ 24pdf index.html)

13）日本外傷データバンク。（https:/ / www.jtcr-jatec.org/ traumabank/dataroom/dataroom.htm)

14）日本外傷学会, 日本脳神経外傷学会：頭部外傷分類, 2008. (http://www.jast-hp.org/zouki/toubu.html)

15）日本脳神経外科学会/日本脳神経外傷学会監修, 重症頭部 外傷治療・管理のガイドライン作成委員会編：重症頭部 外傷治療・管理のガイドライン第 2 版。神経外傷 29 (Suppl) 2006.

16）日本脳神経外科学会/日本脳神経外傷学会監修, 重症頭部 外傷治療・管理のガイドライン作成委員会編：重症頭部 外傷治療・管理のガイドライン第 3 版. 東京, 医学書院, 2013.

17) Stevens RD, Huff JS, Duckworth J, Papangelou A, Weingart SD, Smith WS : Emergency neurological life support: intracranial hypertension and herniation. Neurocrit Care 17 Suppl 1 : S60-S65, 2012.

18）高山泰広，横田裕行：頭部外傷：頭部外傷に伴う凝固線 溶系障害からみた輸液・輸血療法について。救急医学 37：1720-1724，2013.

19）高山泰広，横田裕行，佐藤秀貴，直江康孝，荒木 尚： 頭部外傷に伴う凝固・線溶系障害からみた病態，予後， 治療について。脳外誌 22:837-841，2013.

20） Selladurai S, Reilly P : 高齢者の頭部外傷。横堀將司訳： 横田裕行，荒木 尚監訳：頭部外傷の初期診療。東京， メディカル・サイエンス・インターナショナル，2011, pp.261-268.

21）横堀將司，荒木 尚，恩田秀賢，松本 学，高山泰広, 布施 明，横田裕行：高齢者重症頭部外傷に対する積極 的治療と患者転帰の変遷：頭部外傷データバンク【プロ ジェクト 1998，2004，2009】における検討。神経外傷 36: 76-85, 2013.

22) Yokobori S, Watanabe A, Matsumoto G, Onda H, Masuno T, Fuse A, Kushimoto S, Yokota H: Lower extracellular glucose level prolonged in elderly patients with severe traumatic brain injury: a microdyalysis study. Neurol Med Chir (Tokyo) 51:265-271, 2011.

23) Yokota H, Atsumi T, Araki T, Fuse A, Sato H, Kushimoto S, Koido Y, Kawai M, Yamamoto Y: Cerebral endothelial injury in elderly patients with severe head injury measured by serum thrombomodulin and von Willebrand factor. Neurol Med Chir (Tokyo) 47:383-388, 2007.

24）横田裕行，中村紀夫，荒木 尚，片山容一，河井信行， 木村昭夫，坂本哲也，田崎 修，徳富孝志，藤木 稔， 藤澤博亮, 前田 剛, 三宅康史：外傷医と脳神経外科医 による頭部外傷分類. 神経外傷 $32 ： 18-24 ， 2009$

25）横田裕行, 中村紀夫, 荒木尚, 片山容一, 河井信行, 木 村昭夫, 坂本哲也, 田崎修, 徳富孝志, 藤木 稔, 藤澤 博亮，前田 剛，三宅康史：外傷医と脳神経外科医によ る頭部外傷分類. 日外会誌 25：19-24, 2011. 
外傷学における頭部外傷の位置づけ

一第 28 回日本外傷学会総会・学術集会から一

横田 裕行

重症頭部外傷は, 高い死亡率とさまざまな後遺症の可能性から外傷学の分野でも大きな位置付けが なされている．そのような中で，頭部外傷を合併した多発外傷患者では体幹外傷を専門とする外傷医 と脳神経外科医の密接な連携が必要となるが，本邦における外傷治療は「防ぎ得る外傷死」の回避の ための標準的治療と, 重症頭部外傷治療における治療と管理のガイドラインの発刊によって大きく進 歩してきた. 一方, わが国の著明な高齢化社会を反映して高齢者頭部外傷の増加が大きな問題となつ ている. 高齢者頭部外傷は身体機能の低下, さまざまな既往症の存在から若年者に比較して予後が不 良となる.このような背景から重症頭部外傷, 特に高齢者において病態把握の目的でさまざまな頭蓋 内モニタリングやバイオマーカーの測定が行われている.

以上のような頭部外傷の治療や管理の困難性の共通認識のもとに, 2014 年に日本脳神経外傷学会総 会・学術集会と日本外傷学会総会・学術集会でジョイントシンポジウムが企画された. このシンポジ ウムでは高齢者を含む頭部外傷患者の転帰を改善するための多くの課題や新しい試みなどが議論され た.

脳外誌 $23: 942-950,2014$ 